\title{
IMPLEMENTASI TEKNIK TWO STAY TWO STRAY DALAM PEMBELAJARAN BAHASA INDONESIA SEBAGAI UPAYA MENINGKATKAN HASIL BELAJAR
}

\author{
SUPRI ATMAJA \\ SMP Negeri 1 Pandak \\ Email: atmajasupri68@gmail.com
}

\begin{abstract}
ABSTRAK
Penelitian ini bertujuan untuk meningkatkan hasil belajar siswa dengan menerapkan teknik Two Stay Two Stray pada pembelajaran Bahasa Indonesia. Penelitian ini merupakan jenis penelitian tindakan kelas yang dilakukan di kelas IX A SMP Negeri 1 Pandak. Pengumpulan data dilakukan dengan lembar observasi, tes, dokumentasi, angket, dan wawancara. Data hasil belajar dan partisipasi siswa dalam pembelajaran dianalisis dengan menggunakan teknik deskriptif kuantitatif, sedangkan data pelaksanaan pembelajaran dianalisis menggunakan teknik deskriptif kualitatif. Hasil analisis menunjukkan bahwa hasil belajar siswa mengalami peningkatan. Hal ini dapat dilihat dari peningkatan hasil belajar siswa setiap siklusnya. Hasil belajar sebelum penelitian ketuntasan belajar klasikal hanya $32 \%$, pada siklus I meningkat menjadi $60 \%$, dan pada siklus II meningkat lagi menjadi $80 \%$ dengan rata-rata peningkatan sebesar 29\%. Peningkatan hasil belajar tidak hanya terjadi pada aspek kognitif, tetapi juga pada aspek afektif dan psikomotor. Pada aspek afektif ditunjukkan oleh semakin berkembangnya keterampilan kooperatif siswa, dan pada aspek psikomotor ditunjukkan oleh kemampuan siswa menyusun bahan presentasi.
\end{abstract}

Kata Kunci: Teknik Two Stay Two Stray, Hasil Belajar

\section{ABSTRACT}

This study aims to improve student learning outcomes by applying the Two Stay Two Stray technique in learning Indonesian. This research is a type of classroom action research conducted in class IX A of SMP Negeri 1 Pandak. Data was collected by means of observation sheets, tests, documentation, questionnaires, and interviews. Data on learning outcomes and student participation in learning were analyzed using quantitative descriptive techniques, while data on the implementation of learning were analyzed using qualitative descriptive techniques. The results of the analysis show that student learning outcomes have increased. This can be seen from the increase in student learning outcomes each cycle. The learning outcomes before the classical study completeness study were only $32 \%$, in the first cycle it increased to $60 \%$, and in the second cycle it increased again to $80 \%$ with an average increase of $29 \%$. The increase in learning outcomes does not only occur in the cognitive aspect, but also in the affective and psychomotor aspects. In the affective aspect, it is shown by the development of students' cooperative skills, and in the psychomotor aspect, it is indicated by the ability of students to compose presentation materials.

Keywords: Two Stay Two Stray Technique, Learning Outcomes

\section{PENDAHULUAN}

Masalah aktual dalam dunia pendidikan dewasa ini adalah bagaimana meningkatkan kualitas pembelajaran agar dapat mencapai aktivitas dan hasil belajar yang optimal karena aktivitas dan hasil belajar merupakan tolok ukur keberhasilan proses pembelajaran. Siswa dikatakan berhasil belajaranya apabila siswa dapat mencapai Kriteria Ketuntasan Minimal (KKM). Menurut (Depdiknas, 2007:19) KKM adalah batas minimal pencapaian kompetensi pada setiap aspek penilaian mata pelajaran yang harus dikuasai peserta didik. KKM ditentukan atas kesepakatan kelompok guru mata pelajaran berdasarkan hasil analisis SWOT satuan pendidikan yang bersangkutan. Berdasarkan hasil kesepakatan bersama guru mata pelajaran Bahasa Indonesia di SMP Negeri 1 Pandak ditetapkan bahwa KKM mata pelajaran Bahasa 
Indonesia sebesar 70, dengan ketuntasan klasikal 80\%. Hal ini berarti bahwa seorang siswa dikatakan telah berhasil atau tuntas belajarnya jika telah mencapai nilai 70 , dan kelas dinyatakan telah berhasil atau tuntas belajarnya apabila sekurang-kurangnya $80 \%$ siswa telah berhasil atau tuntas belajarnya. Namun, kenyataan yang ditemukan pada pembelajaran Bahasa Indonesia di kelas IX A SMP Negeri 1 Pandak menunjukkan bahwa terdapat 68\% siswa belum mencapai KKM. Berdasarkan analisis hasil tes awal diketahui bahwa siswa yang mencapai KKM hanya 32\% atau 10 anak dari 32 siswa, dengan rata-rata nilai 64. Pembelajaran yang efektif adalah pembelajaran yang menyediakan kesempatan belajar sendiri atau melakukan aktivitas sendiri. Proses pembelajaran yang dilakukan di dalam kelas merupakan aktivitas menstranformasi pengetahuan, sikap, dan keterampilan (Yamin, 2007:75). Saat pembelajaran berlangsung siswa mampu memberikan umpan balik terhadap guru. Aktivitas belajar dapat terwujud apabila siswa terlibat secara aktif.

(Sardiman, 2006:100) menyatakan bahwa aktivitas belajar merupakan aktivitas yang berupa fisik maupun mental. Dalam kegiatan belajar keduanya saling berkaitan. (Hamalik, 2009:179) menyatakan bahwa aktivitas belajar merupakan kegiatan yang dilakukan siswa dalam kegiatan pembelajaran. Dalam UNION: Jurnal Pendidikan Matematika (Fathonah dan Yudhawati, 2019:362)) menyatakan bahwa siswa akan mengikuti kegiatan proses belajar secara pasif apabila guru yang selalu menjadi pusat dan sumber belajar bagi siswa.

Sedangkan istilah hasil belajar dapat diartikan sebagai kemampuan baru sama sekali atau dapat juga berupa penyempurnaan maupun pengembangan dari suatu kemampuan yang telah dimiliki seseorang yang diperoleh dari proses belajar (W.S. Winkel, 1987:38). Berdasarkan pengertian tersebut dapat di simpulkan bahwa ada dua hasil belajar yaitu yang satu memang dituju sedangkan yang lain tidak, hasil yang kedua merupakan efek sampingan, sedangkan hasil yang dituju adalah merupakan kemampuan yang baru, atau bisa penyempurnaan kemampuan yang telah dimiliki. Menurut (Sudjana, 2005:111) hasil belajar adalah bentuk tingkah laku yang dimiliki siswa setelah menyelesaikan pengalaman belajar. Bentuk tingkah laku sebagai hasil belajar dapat berupa memberi reaksi terhadap rangsangan, asosiasi verbal, mengemukakan konsep, prinsip, dan memecahkan masalah. Hasil belajar biasanya diperoleh setelah siswa dinyatakan berhasil dalam suatu penilaian yang dilkukan pada akhir pembelajaran. Hasil belajar pada hakekatnya tersirat dalam tujuan pembelajaran. Oleh sebab itu hasil belajar siswa di sekolah dipengaruhi oleh kemampuan siswa dan kualitas pembelajaran. Dalam jurnal Media Manajemen Pendidikan (Siti Chotimah dan Mundilarno, 2020) menyatakan bahwa hasil belajar siswa merupakan salah satu hal yang dapat untuk menentukan kebijaksaan sekolah.

Teknik Two Stay Two Stray merupakan salah satu teknik dalam cooperative lerning. Teknik belajar mengajar Dua Tinggal Dua Tamu (Two Stay Two Stray) dikembangkan oleh Spencer Kagan dan bisa digunakan bersama dengan Teknik Kepala Bernomor. Teknik ini bisa digunakan dalam semua mata pelajaran dan untuk semua tingkatan usia anak didik. (Lie, 2007:61) mengemukakan bahwa struktur Dua Tinggal Dua Tamu memberi kesempatan kepada kelompok untuk membagikan hasil dan informasi dengan kelompok lain. Banyak kegiatan belajar mengajar yang diwarnai dengan kegiatan individu. Siswa bekerja sendiri dan tidak diperbolehkan melihat pekerjaan siswa yang lain. Padahal dalam kenyataan hidup di luar sekolah, kehidupan dan kerja manusia saling bergantung satu dengan lainnya.

Menurut (Johnson \& Jhonson, 1989:12) kooperatif diartikan sebagai belajar bersama (cooperative learning) untuk mencapai tujuan. Belajar bersama mempunyai keunggulan sebagai berikut: 1) adanya saling ketergantungan yang positif dalam kelompok belajar siswa, 2) membuat siswa berinteraksi selama menyelesaikan tugas dan yakin bahwa interaksi sesuai dengan tugas, 3) membuat semua siswa bertanggungjawab secara individual untuk menyelesaikan tugas, dan 4) membiarkan siswa belajar menggunakan keterampilan interpersonal dan kelompok kecil. Berdasarkan keunggulan-keunggulan tersebut maka teknik Two Stay Two Stray dipilih sebagai alternatif strategi pembelajaran dalam rangka meningkatkan aktivitas dan hasil belajar siswa. 
Berdasarkan hasil dialog bersama dengan guru Bahasa Indonesia, ditemukan beberapa faktor penyebab rendahnya hasil belajar siswa kelas IX A tersebut. Faktor tersebut adalah metode mengajar guru yang kurang melibatkan siswa. Guru masih mendominasi pembelajaran sehingga interaksi hanya berlangsung satu arah. Kondisi ini menyebabkan siswa cenderung pasif dan kurang inisiatif sehingga mereka lebih banyak menunggu sajian guru daripada mencari dan menemukan sendiri pengetahuan dan keterampilan yang mereka butuhkan. Siswa tidak terbiasa belajar secara mandiri untuk menemukan, mengembangkan dan menyampaikan ide atau gagasannya baik dalam berinteraksi dengan siswa lain maupun guru.

Mencermati berbagai kecenderungan situasi yang muncul pada kelas IX A SMP Negeri 1 Pandak tersebut sangat perlu adanya implementasi atau inovasi metode pembelajaran yang efektif. Salah satu alternatif untuk mengatasi masalah hasil belajar yang rendah tersebut guru menerapkan pembelajaran dengan teknik Two Stay Two Stray. Menurut (Lie, 2005:61) teknik Two Stay Two Stray merupakan salah satu teknik dalam pembelajaran kooperatif yang memberi kesempatan kepada kelompok untuk membagikan hasil dan informasi dengan kelompok lain. Pada teknik ini setiap kelompok mendapatkan materi yang berbeda. Setelah selesai berdiskusi pada kelompok masing-masing, perwakilan setiap kelompok akan mengunjungi kelompok lain sehingga pada akhirnya setiap kelompok akan menguasai materi pembelajaran secara utuh.

Teknik Two Stay Two ini memungkinkan siswa untuk didengar suaranya, dihargai, dan diakui keberadaannnya melalui diskusi dalam kelompoknya sendiri, diskusi dengan kelompok lain ketika melakukan kunjungan kelompok, dan pemberian kesempatan untuk melakukan presentasi hasil diskusi. Disamping itu, siswa juga diberi kesempatan untuk menggali pengetahuannya dengan menggunakan imajinasi yang dimilikinya melalui pemberian tugas. Teknik Two Stay Two Stray merupakan inovasi yang dikembangkan dalam rangka mengatasi permasalahan hasil belajar siswa yang rendah.

Berdasarkan analisis situasi di kelas IX A SMP Negeri 1 Pandak, maka rumusan masalah dalam penelitian ini adalah "Bagaimanakah peningkatan hasil belajar siswa setelah mengikuti pembelajaran Bahasa Indonesia dengan teknik Two Stay Two Stray?" Penelitian ini bertujuan meningkatkan hasil belajar siswa setelah digunakan teknik Two Stay Two Stray dalam pembelajaran.

\section{METODE PENELITIAN}

Penelitian ini menggunakan pendekatan kuantitatif dan kualitatif. Data hasil belajar dan partisipasi siswa dalam pembelajaran dianalisis dengan menggunakan teknik deskriptif kuantitatif, sedangkan data pelaksanaan pembelajaran dianalisis menggunakan teknik deskriptif kualitatif. Penelitian dilaksanakan tanggal 23 Juli 2019 sampai 29 Oktober 2019 pada semester ganjil tahun pelajaran 2019/2020.

Penelitian dilaksanakan di SMP Negeri 1 Pandak dengan lokasi sekolah berada di wilayah Kabupaten Bantul. SMP Negeri 1 Pandak dipilih sebagai tempat penelitian dengan alasan peneliti adalah guru di sekolah tersebut. Dalam penelitian ini peneliti bertindak sebagai guru model, dan kolaborator bertindak sebagai observer dengan alasan peneliti guru mata pelajaran di kelas IX A dan sekaligus penyusun skenario pembelajaran.

Subjek penelitian ini adalah siswa kelas IX A SMP Negeri 1 Pandak, Bantul pada semester ganjil Tahun Pelajaran 2019/2020, yang berjumlah 32 siswa. Kelas IX A dipilih sebagai subjek penelitian karena memiliki karakteristik berupa hasil belajar yang rendah dan pembelajaran Bahasa Indonesia yang berpusat pada guru.

Teknik pengumpulan data adalah cara-cara yang digunakan peneliti untuk memperoleh data-data guna menjawab rumusan masalah penelitian. Untuk memperoleh data-data penelitian tersebut disusun instrumen penelitian berdasarkan kajian teori dan diskusi dengan expert. Dalam penelitian ini terdapat lima teknik pengumpulan data yang digunakan yaitu pengamatan, tes, dokumentasi, angket dan wawancara.

Instrumen yang digunakan selama pengamatan adalah lembar pegamatan yang berisi kisikisi pengamatan agar pencatatan pengamatan lebih sistematis. Dalam penelitian ini akan 
dilakukan pengamatan terhadap pelaksanaan kegiatan pembelajaran dengan teknik Two Stay Two Stray serta pengamatan terhadap partisipasi siswa dalam pembelajaran. Kisi-kisi pengamatan pelaksanaan pembelajaran disusun berdasarkan prinsip-prinsip pada pembelajaran dengan menggunakan teknik Two Stay Two Stray yang meliputi perencanaan pembelajaran, pelaksanaan pembelajaran dan hal-hal yang menonjol yang muncul selama proses pembelajaran. Dalam lembar pengamatan ini disediakan dua alternatif jawaban yaitu "ya" dan " tidak" jika kegiatan tidak dilaksanakan. Di samping itu pengamat disediakan tempat untuk membuat catatan pengamatan guna merekam kejadian yang tak terduga.

\section{HASIL DAN PEMBAHASAN}

\section{Hasil Penelitan Prasiklus}

Sebelum pembelajaran pada siklus I, guru menjelaskan kepada siswa mengenai teknik Two Stay Two Stray. Guru juga menjelaskan cara penilaian yang digunakan kepada siswa dan sikapsikap yang harus dikembangkan oleh siswa selama berdiskusi dalam pembelajaran kooperatif dengan teknik Two Stay Two Stray. Pada tahap ini guru juga melakukan tes awal untuk mengetahui hasil belajar siswa sebelum pembelajaran dengan teknik Two Stay Two Stray.

Tabel 1 Rangkuman Analisis Data Hasil Belajar Siswa Prasiklus

\begin{tabular}{|c|c|c|c|c|c|c|c|c|}
\hline & \multirow{2}{*}{$\begin{array}{c}\text { Jumlah } \\
\text { Siswa }\end{array}$} & $\begin{array}{c}\text { Nilai } \\
\text { Terting-gi }\end{array}$ & \multirow{2}{*}{$\begin{array}{c}\text { Nilai } \\
\text { Teren } \\
\text { dah }\end{array}$} & $\begin{array}{c}\text { Nilai } \\
\text { Rata-rata } \\
\text { kelas }\end{array}$ & \multicolumn{2}{|c|}{$\begin{array}{c}\text { Siswa yang } \\
\text { Tuntas }\end{array}$} & \multicolumn{2}{|c|}{$\begin{array}{c}\text { Siswa yang } \\
\text { belum tuntas }\end{array}$} \\
\cline { 5 - 9 } & & & & lah & $\begin{array}{c}\text { Persen } \\
(\%)\end{array}$ & $\begin{array}{c}\text { Jum- } \\
\text { lah }\end{array}$ & $\begin{array}{c}\text { Persen } \\
(\%)\end{array}$ \\
\hline 1 & 32 & 80 & 50 & 66 & 10 & 32 & 22 & 68 \\
\hline
\end{tabular}

Hasil tes menunjukkan bahwa siswa yang telah tuntas belajarnya atau telah mencapai KKM baru 32\%, sedangkan yang belum mencapai KKM sebesar 68\%, berarti di kelas IX A ketuntasan klasikal baru 32\%. Hal ini tidak sesuai dengan Kriteria Ketuntasan Minimal ideal yang telah ditetapkan dalam Kurikulum Tingkat Satuan Pendidikan (KTSP) SMP Negeri 1 Pandak yang menyatakan bahwa suatu kelas dikatakan telah tuntas belajarnya apabila sekurang-kurangnya $80 \%$ siswa telah mencapai KKM. Hal ini disebabkan karena pembelajaran yang cenderung berpusat pada guru sehingga siswa kurang termotivasi untuk mengikuti pembelajaran. Disamping itu siswa tidak mempunyai kesempatan untuk terlibat aktif dalam pembelajaran, akibatnya siswa cenderung pasif. Suasana pembelajaran juga monoton dan kurang menyenangkan.

\section{Hasil Penelitian Siklus I}

Penelitian Tindakan Kelas pada siklus I dilaksanakan pada tanggal 23 Juli sampai 13 Agustus 2019 selama tiga kali pertemuan. Pada siklus I ini Kompetensi Dasar yang direncanakan untuk dikuasai oleh siswa adalah mengidentifikasi unsur kebahasaan dalam teks laporan percobaan.

Pelaksanaan tindakan siklus I dimulai pada tanggal 30 Juli 2019 untuk pertemuan ke- 1, tanggal 6 Agustus 2019 untuk pertemuan ke- 2, dan tanggal 13 Agustus 2019 untuk pertemuan ke-3. Pelaksanaan Siklus I menggunakan skenario tindakan sebagai berikut:

Pendahuluan (15 menit)

Pelaksanaan pembelajaran dimulai dengan presensi kelas oleh guru. Guru kemudian menjelaskan tujuan pembelajaran dan mengingatkan cara penilaian yang akan digunakan. Guru memberikan apersepsi dengan cara mengaitkan materi pelajaran dengan contoh kehidupan sehari-hari. Motivasi dilakukan oleh guru dengan menunjukkan ciri kebahasaan dalam teks laporan percobaan dan bertanya jawab berdasarkan pengetahuan mereka. Kemudian guru membagi kelompok. Guru menjelaskan langkah-langkah kegiatan pembelajaran.

Siswa duduk dalam kelompoknya masing-masing untuk berdiskusi. Guru membagikan teks laporan percobaan kepada setiap kelompok. Setiap kelompok diminta untuk 
mendiskusikan unsur kebahasaan yang ada dalam teks laporan percobaan. Setelah selesai diskusi setiap kelompok membagi tugas pada kelompoknya masing- masing. Dua orang bertugas sebagai penerima tamu dan dua orang bertugas sebagai tamu. Sebelum kunjungan dimulai guru memimpin ice breaking untuk mengendorkan urat syaraf dengan senam ringan. Selanjutnya kegiatan kunjungan dimulai, bagi yang bertugas sebagai tamu mengunjungi kelompok lain secara bergiliran sedangkan yang bertugas sebagai penerima tamu menunggu tamu di tempat duduknya.

Selama proses diskusi maupun kunjungan, guru memutarkan musik instrumentalia klasik untuk memfungsikan belahan otak kanan siswa. Setelah selesai diskusi diadakan presentasi hasil kerja kelompok. Kemudian guru memberikan pembahasan dan penguatan hasil presentasi siswa.

Penutup pembelajaran meliputi kegiatan antara lain: (1) guru bersama- sama siswa menyimpulkan materi pembelajaran, kemudian guru melakukan refleksi dengan menanyakan kesan-kesan siswa terhadap pembelajaran yang telah diikuti. Guru memberikan penugasan untuk mempelajari materi pertemuan berikutnya. Sebagai penutup kegiatan dilakukan perayaan kelas dengan bernyanyi bersama. Pada akhir pertemuan ke-3 kegiatan penutup dilakukan dengan pemberian tes hasil belajar untuk mengetahui ketercapaian.

Tabel 2 Rangkuman Analisis Data Hasil Belajar Siswa Siklus I

\begin{tabular}{|c|c|c|c|c|c|c|c|c|}
\hline No & $\begin{array}{c}\text { Jumlah } \\
\text { Siswa }\end{array}$ & $\begin{array}{c}\text { Nerting- } \\
\text { gi }\end{array}$ & $\begin{array}{c}\text { Nilai } \\
\text { Teren } \\
\text { dah }\end{array}$ & $\begin{array}{c}\text { Nilai } \\
\text { Rata- } \\
\text { rata } \\
\text { kelas }\end{array}$ & \multicolumn{2}{|c|}{$\begin{array}{c}\text { Siswa yang } \\
\text { Tuntas }\end{array}$} & \multicolumn{2}{|c|}{$\begin{array}{c}\text { Siswa yang } \\
\text { belum tuntas }\end{array}$} \\
\cline { 5 - 9 } & & & $\begin{array}{c}\text { Persen } \\
(\%)\end{array}$ & $\begin{array}{c}\text { Jum- } \\
\text { lah }\end{array}$ & $\begin{array}{c}\text { Persen } \\
(\%)\end{array}$ \\
\hline 1 & 32 & 90 & 60 & 73 & 19 & 60 & 13 & 40 \\
\hline
\end{tabular}

Hasil tes (tabel 2) menunjukkan bahwa siswa yang belum tuntas atau belum mencapai KKM sebesar $40 \%$ sedangkan siswa yang telah tuntas belajarnya baru $60 \%$. Rata-rata hasil belajar siswa pada siklus I ini sebesar 73. Berdasarkan hasil tes tesebut maka pada siklus I ini keberhasilan penelitian belum tercapai. Namun, jika dibandingkan dengan sebelum pelaksanaan penelitian maka terjadi peningkatan hasil belajar yang cukup signifikan.

Pada prapenelitian ketuntasan klasikal baru 32\% tetapi pada siklus I ini menjadi $60 \%$ berarti terjadi peningkatan sebesar $28 \%$. Peningkatan ketuntasan kelas ini terjadi karena siswa mengkonstruksi pengetahuannya sendiri melalui diskusi kelompok sehingga siswa memahami materi bukan hanya mengingat materi. Kondisi seperti ini akan meningkatkan daya serap siswa terhadap materi pembelajaran. Peningkatan daya serap siswa ini akan berdampak pada kemampuan memecahkan soal tes. Peningkatan ini juga disebabkan oleh keterlibatan atau keaktifan siswa dalam pembelajaran. Keterlibatan ini berdampak pada peningkatan pemahaman siswa, karena siswa mendengar, mengalami dan melakukan sendiri sehingga siswa cenderung lebih mudah menguasai materi pelajaran.

Proses pembelajaran untuk mengukur aktivitas belajar diamati dengan menggunakan lembar pengamatan terhadap partisipasi siswa pada saat diskusi yang diukur dengan menggunakan indikator keterampilan kooperatif yang dikuasai siswa dalam pembelajaran dengan teknik Two Stay Two Stray. Adapun hasil pengamatan terhadap partisipasi siswa seperti tabel 3 di bawah ini.

Tabel 3 Persentase Tingkat Keterampilan Kooperatif Siswa Siklus I

\begin{tabular}{|c|c|c|c|}
\hline \multirow{2}{*}{ Kualifikasi } & \multicolumn{3}{|c|}{ Keterampilan Kooperatif } \\
\cline { 2 - 4 } & Dasar & Menengah & Atas \\
\hline Kurang & 0 & 5 & 40 \\
\hline Cukup & 58 & 63 & 45 \\
\hline Tinggi & 43 & 33 & 15 \\
\hline
\end{tabular}


Tabel 3 menunjukkan bahwa pada siklus I keterampilan kooperatif siswa mulai berkembang, baik keterampilan kooperatif dasar, menengah, maupun atas. Keterampilan kooperatif siswa pada siklus I ini rata-rata baru pada kualifikasi cukup. Hal ini terjadi karena siswa belum terbiasa menggunakan strategi pembelajaran dengan teknik Two Stay Two Stray Selama ini siswa terbiasa dengan metode ceramah sehingga siswa masih terlihat malu-malu dan takut untuk mengemukakan pendapat.

\section{Hasil Penelitian Siklus II}

Penelitian Tindakan Kelas pada siklus II dilaksanakan pada tanggal 3 sampai 30 September 2019 selama tiga kali pertemuan. Pada siklus II ini Kompetensi Dasar yang direncanakan untuk dikuasai oleh siswa adalah mengidentifikasi ciri-ciri setiap unsur kebahasaan dalam teks laporan percobaan dan penggunaannya dalam kalimat.

Pelaksanaan tindakan siklus II dimulai pada tanggal 3 September 2019 untuk pertemuan ke-1, tanggal 10 September 2019 untuk pertemuan ke-2, dan tanggal 17 September 2019 untuk pertemuan ke-3. Pelaksanaan Siklus II menggunakan skenario tindakan sebagai berikut:

Pendahuluan (15 menit)

Pelaksanaan pembelajaran dimulai dengan presensi kelas oleh guru. Guru kemudian menjelaskan tujuan pembelajaran dan mengingatkan cara penilaian yang akan digunakan. Guru memberikan apersepsi dengan cara mengaitkan materi pelajaran dengan contoh kehidupan sehari-hari. Motivasi dilakukan oleh guru dengan menyanyi bersama. Kemudian guru membagi kelompok. Guru menjelaskan langkah-langkah kegiatan pembelajaran.

Kegiatan Inti (50 menit)

Siswa duduk dalam kelompoknya masing-masing untuk berdiskusi. Guru membagikan teks laporan percobaan Guru juga membagikan Resume Materi kepada setiap kelompok. Setiap kelompok juga diminta untuk menyediakan buku sumber atau sumber-sumber lain yang relevan dengan materi pelajaran. Setiap kelompok mempunyai tugas untuk menganalisis unsur kebahasaan teks laporan percobaan, menentukan ciri serta memberi contoh kalimat dengan bantuan resume materi dan buku sumber atau sumber-sumber lain.

Setelah selesai diskusi setiap kelompok membagi tugas pada kelompoknya masingmasing. Dua orang bertugas sebagai penerima tamu dan dua orang bertugas sebagai tamu. Sebelum kunjungan dimulai guru memimpin ice breaking untuk mengendorkan urat syaraf dengan saling memijat antarsiswa. Selanjutnya kegiatan kunjungan dimulai, bagi yang bertugas sebagai tamu mengunjungi kelompok lain secara bergiliran sedangkan yang bertugas sebagai penerima tamu menunggu tamu di tempat duduknya.

Selama proses diskusi maupun kunjungan, guru memutarkan musik instrumentalia klasik untuk memfungsikan belahan otak kanan siswa. Setelah selesai diskusi diadakan presentasi hasil kerja kelompok. Kemudian guru memberikan pembahasan dan penguatan hasil presentasi siswa.

Penutup (15 menit)

Penutup pembelajaran meliputi kegiatan antara lain: (1) guru bersama- sama siswa menyimpulkan materi pembelajaran, kemudian guru melakukan refleksi dengan menanyakan kesan-kesan siswa terhadap pembelajaran yang telah diikuti. Guru memberikan penugasan untuk mempelajari materi pertemuan berikutnya. Sebagai penutup kegiatan dilakukan perayaan kelas dengan tepuk tangan dan meneriakkan yel-yel bersama. Pada akhir pertemuan ke-3 kegiatan penutup dilakukan dengan pemberian tes hasil belajar untuk mengetahui ketercapaian tujuan pembelajaran. Setelah selesai mengerjakan tes, siswa mengisi angket sikap siswa terhadap kegiatan pembelajaran dengan teknik Two Stay Two Stray. 
Tabel 4 Rangkuman Analisis Data Hasil Belajar Siswa Siklus II

\begin{tabular}{|c|c|c|c|c|c|c|c|c|}
\hline \multirow[t]{2}{*}{ No. } & \multirow[t]{2}{*}{$\begin{array}{c}\text { Jumlah } \\
\text { Siswa }\end{array}$} & \multirow[t]{2}{*}{$\begin{array}{c}\text { Nilai } \\
\text { Tertinggi }\end{array}$} & \multirow{2}{*}{$\begin{array}{c}\text { Nilai } \\
\text { Teren } \\
\text { dah }\end{array}$} & \multirow{2}{*}{$\begin{array}{l}\text { Nilai } \\
\text { Rata- } \\
\text { rata } \\
\text { kelas }\end{array}$} & \multicolumn{2}{|c|}{$\begin{array}{c}\text { Siswa yang } \\
\text { Tuntas }\end{array}$} & \multicolumn{2}{|c|}{$\begin{array}{c}\text { Siswa yang } \\
\text { belum tuntas }\end{array}$} \\
\hline & & & & & $\begin{array}{l}\text { Jum- } \\
\text { lah }\end{array}$ & $\begin{array}{c}\text { Persen } \\
(\%)\end{array}$ & $\begin{array}{l}\text { Jum- } \\
\text { lah }\end{array}$ & $\begin{array}{c}\text { Persen } \\
(\%)\end{array}$ \\
\hline 1 & 32 & 90 & 60 & 79 & 26 & 80 & 6 & 20 \\
\hline
\end{tabular}

Hasil tes (tabel 4) menunjukkan bahwa siswa yang belum tuntas atau belum mencapai KKM sebesar $20 \%$ sedangkan siswa yang telah tuntas belajarnya baru $80 \%$. Rata-rata hasil belajar siswa pada siklus II ini sebesar 80 . Berdasarkan hasil tes tesebut maka pada siklus II ini keberhasilan penelitian telah tercapai.

Ketercapaian ketuntasan klasikal ini disebabkan oleh peningkatan kualitas pembelajaran yang ditunjukkan oleh interaksi yang harmonis antara guru dengan siswa dan partisipasi aktif siswa dalam pembelajaran. Pada akhir pembelajaran, bahan hasil diskusi yang telah ditulis siswa dikumpulkan sebagai portofolio. Hasil karya siswa tersebut menunjukkan bahwa psikomotorik siswa dalam pembelajaran dengan teknik Two Stay Two Stray juga berkembang.

Disamping itu, berdasarkan hasil pengisian angket sikap siswa terhadap pembelajaran dengan Teknik TwoStay Two Stray diketahui 95\% siswa merasa senang mengikuti pembelajaran, $75 \%$ siswa menyatakan tertantang dengan tugas yang diberikan, dan $95 \%$ siswa menyatakan bahwa diskusi kelompok bermanfaat.

Seperti pada siklus I, proses pembelajaran diamati dengan menggunakan lembar pengamatan terhadap partisipasi dan keaktifan siswa pada saat diskusi yang diukur dengan menggunakan indikator keterampilan kooperatif yang dikuasai siswa dalam pembelajaran dengan teknik Two Stay Two Stray. Adapun hasil pengamatan terhadap partisipasi siswa seperti tabel 5 di bawah ini.

Tabel 5 Persentase Tingkat Keterampilan Kooperatif Siswa Siklus II

\begin{tabular}{|l|c|r|c|}
\hline \multirow{2}{*}{ Kualifikasi } & \multicolumn{3}{|c|}{ Keterampilan Kooperatif } \\
\cline { 2 - 4 } & Dasar & Menengah & Atas \\
\hline Kurang & 0 & 0 & 0 \\
\hline Cukup & 28 & 35 & 63 \\
\hline Tinggi & 73 & 65 & 38 \\
\hline
\end{tabular}

Tabel 5 menunjukkan bahwa pada siklus II keterampilan kooperatif siswa semakin meningkat, baik keterampilan kooperatif dasar, menengah, maupun atas. Keterampilan kooperatif dasar dan menengah mayoritas siswa mencapai kualifikasi tinggi, yaitu pada keterampilan kooperatif dasar $73 \%$ siswa mencapai kualifikasi tinggi dan pada keterampilan kooperatif menengah 65\% siswa mencapai kualifikasi tinggi. Pada keterampilan kooperatif atas 63\% siswa baru mencapai kualifikasi cukup hal ini menunjukkan bahwa mayoritas siswa baru mencapai kualifikasi cukup, sedangkan kualifikasi tinggi baru tercapai oleh 38\% siswa. Pada siklus II ini baik pada keterampilan kooperatif dasar, menengah, maupun atas sudah tidak ditemukan lagi siswa yang mencapai kualifikasi kurang.

\section{Pembahasan}

Proses pembelajaran dalam penelitian ini dilaksanakan dua siklus dengan materi mengidentifikasi unsur kebahasaan teks laporan percobaan. Proses pembelajaran menerapkan teknik Two Stay Two Stray. Hasil pembelajaran terhadap materi tentang mengidentifikasi unsur kebahasaan teks laporan percobaan di kelas IXA dengan menggunakan teknik Two Stay Two Stray pada siklus I dan siklus II mampu membawa perubahan hasil belajar siswa secara signifikan. Penggunaan teknik ini tidak hanya mampu meningkatkan hasil belajar siswa tetapi juga mampu meningkatkan aktivitas pembelajaran. Sebelum diterapkan teknik ini atau prasiklus, pembelajaran cenderung pasif dan hasil belajar siswa yang rendah. Hal ini bisa dilihat 
dari pencapaian nilai kompetensi belajar siswa siklus I dan siklus II yang mengalami peningkatan.

Hasil tes awal menunjukkan bahwa siswa yang telah tuntas belajarnya atau telah mencapai KKM baru 32\%, sedangkan yang belum mencapai KKM sebesar 68\%, berarti di kelas IXA ketuntasan klasikal baru 32\%. Hal ini tidak sesuai dengan Kriteria Ketuntasan Minimal ideal yang telah ditetapkan dalam Kurikulum Tingkat Satuan Pendidikan (KTSP) SMP Negeri 1 Pandak yang menyatakan bahwa suatu kelas dikatakan telah tuntas belajarnya apabila sekurang-kurangnya $80 \%$ siswa telah mencapai KKM. Hal ini disebabkan karena pembelajaran yang cenderung berpusat pada guru sehingga siswa kurang termotivasi untuk mengikuti pembelajaran. Disamping itu siswa tidak mempunyai kesempatan untuk terlibat aktif dalam pembelajaran. Suasana pembelajaran juga monoton dan kurang menyenangkan.

Berdasarkan hasil analisis pada siklus I dan II dapat dibuat perbandingan bahwa penguasaan keterampilan kooperatif siswa sebagai indikator aktivitas belajar siswa selalu mengalami peningkatan pada setiap siklusnya.

Peningkatan aktivitas belajar dalam penelitian ini sesuai dengan penelitian Husnul Chotimah yang mengatakan bahwa pembelajaran dengan model pembelajaran Two Stay Two Stray mampu menciptakan suasana pembelajaran yang lebih aktif dan mampu membangun antusias siswa. Siswa menjadi lebih aktif, berani, dan bersemangat. Pada kondisi awal (pratindakan) siswa cenderung diam dan kurang berani. Siswa juga masih belum kompak dan setiap anggota kelompok kurang bekerjasama dengan baik, inisiatif kerja siswa dalam kelompok masih kurang dan memotivasi antar anggota kelompok juga masih kurang. Selain itu, keaktifan siswa masih belum terlalu terlihat. Siswa cenderung tenang dan pasif, serta belum aktif (Chotimah,2017: 38).

Hasil belajar siswa dari aspek kognitif yang menggambarkan keterserapan materi oleh siswa diukur dengan tes hasil belajar atau tes siklus. Nilai tes menentukan ketuntasan belajar siswa. Dalam penelitian ini, telah tercapai ketuntasan klasikal pada siklus II yaitu sebesar $80 \%$, berarti terdapat $80 \%$ siswa yang telah mencapai KKM atau telah tuntas belajarnya. Pada siklus I ketuntasan klasikal baru $60 \%$, pada siklus II meningkat menjadi $80 \%$, berarti terjadi peningkatan sebesar $20 \%$.

Peningkatan hasil belajar tersebut disebabkan oleh peningkatan kualitas proses pembelajaran. Siswa berpartisipasi aktif dalam pembelajaran melalui diskusi kelas. Dalam proses diskusi tersebut aktivitas belajar siswa berkembang, disamping itu siswa mempunyai kesempatan untuk membangun dan mengkonstruksi pengetahuannya, sedangkan guru berperan sebagai fasilitator dan pembimbing siswa. Pengetahuan yang diperoleh dengan cara membangun sendiri pengetahuannya akan lama mengendap dalam pikiran siswa dan memudahkan siswa untuk menyerap materi.

Peningkatan hasil belajar dalam penelitian ini sesuai dengan penelitian yang mengatakan bahwa pembelajaran kooperatif Two Stay Two Stray selain dapat meningkatkan prestasi belajar kognitif siswa juga dapat meningkatkan motivasi dan hasil belajar siswa (Fitriyah: 2012: 133). Hal tersebut juga sesuai dengan hasil penelitian yang dilakukan oleh (Sari, 2010:134) bahwa penerapan pembelajaran kooperatif Two Stay Two Stray dapat meningkatkan motivasi dan hasil belajar siswa.

Penelitian lain yang dilakukan oleh Asep (2016:115) mengatakan bahwa dengan menggunakan teknik Jigsaw dapat meningkatkan hasil belajar siswa pada mata pelajaran Bahasa Indonesia dengan materi menemukan kalimat utama pada paragraf. Namun demikian, teknik Two Stay Two Stray penerapannya lebih mudah dan sederhana dibandingkan dengan teknik Jigsaw. Dalam penerapan teknik Two Stay Two Stray tidak perlu membentuk kelompok asal dan kelompok ahli. Semua siswa dianggap memiliki kemampuan yang sama sehingga mereka merasa tidak dibeda-bedakan. Salah satu kekurangan teknik Jigsaw adalah siswa yang memiliki kemampuan membaca dan berpikir rendah akan mengalami kesulitan untuk menjelaskan materi apabila ditunjuk sebagai kelompok ahli. 
Peningkatan hasil belajar kognitif siswa dengan model TSTSdisebabkan karena dengan adanya kegiatan stay dan stray, siswa yang melakukan kegiatan stray akan bertanya mengenai materi yang belum dipahami kepada kelompok lain dan siswa yang melakukan kegiatan stay akan Peningkatan hasil belajar kognitif siswa dengan model TSTSdisebabkan karena dengan adanya kegiatan stay dan stray, siswa yang melakukan kegiatan stray akan bertanya mengenai materi yang belum dipahami kepada kelompok lain dan siswa yang melakukan kegiatan stay akan saling berbagi informasi yang diketahui sehingga siswa lebih memahami materi.

Teknik Two Stay Two Stray memiliki beberapa kelebihan diantaranya (1) Dapat diterapkan pada semua tingkatan dan mata pelajaran, (2) Kecenderungan belajar siswa menjadi lebih bermakna, (3) Lebih berorientasi pada keaktifan, (4) Siswa berani mengungkapkan pendapatnya, (5) Menambah kekompakan dan rasa percaya diri, (6) Kemampuan bicara siswa bisa meningkat, (7) Membantu meningkatkan minat dan hasil belajar. Di samping memiliki kelebihan tentu teknik ini juga memiliki kekurangan diantaranya (1) membutuhkan waktu yang lama, (2) membutuhkan banyak persiapan, (3) Adanya kesulitan dalam pengelolaan kelas.

\section{KESIMPULAN}

Berdasarkan hasil penelitian dan pembahasan dapat disimpulkan bahwa pembelajaran Bahasa Indonesia dengan menerapkan teknik Two Stay Two Stray dapat meningkatkan hasil belajar siswa. Hal ini dapat dilihat dari peningkatan hasil belajar siswa setiap siklusnya. Sebelum penelitian ketuntasan belajar klasikal hanya 32\%, pada siklus I meningkat menjadi $60 \%$, dan pada siklus II meningkat lagi menjadi $80 \%$ dengan rata-rata peningkatan sebesar 29\%. Peningkatan hasil belajar tidak hanya terjadi pada aspek kognitif, tetapi juga pada aspek afektif dan psikomotor. Pada aspek afektif ditunjukkan oleh semakin berkembangnya keterampilan kooperatif siswa, dan pada aspek psikomotor ditunjukkan oleh kemampuan siswa menyusun bahan presentasi.

Penerapan teknik Two Stay Two Stray pada pembelajaran Bahasa Indonesia dengan memperhatikan ukuran ruang kelas, jenis meja kursi, dan banyaknya siswa perlu dipertimbangkan agar proporsional sehingga memudahkan mobilitas siswa dalam perpindahan kelompok, bobot materi sebagai tugas siswa disesuaikan dengan kemampuan siswa agar diskusi tidak menghabiskan banyak waktu, guru lebih banyak terlibat dalam bimbingan kelompok, sehingga untuk proses penilaian atau pengamatan diperlukan satu atau dua orang observer, guru membuat skenario untuk motivasi dan ice breaking yang bervariasi agar dapat menumbuhkan motivasi siswa.

Dari penelitian ini terbukti bahwa pembelajaran dengan teknik Two Stay Two Stray mampu meningkatkan hasil belajar siswa sekaligus mampu meningkatkan aktivitas siswa. Sehubungan dengan itu, diharapkan para guru mampu berinovasi dalam melaksanakan pembelajaran dengan meninggalkan gaya mengajar yang selama ini mungkin dilakukan yaitu pembelajaran satu arah. Teknik Two Stay Two Stray menjadi salah satu alternatif pembelajaran yang mampu membuat siswa menjadi aktif. Siswa mampu menemukan sendiri pengetahuan yang dipelajarinya sehingga akan tersimpan lama dalam memori ingatan sekaligus mampu meningkatkan hasil belajar mereka.

\section{DAFTAR PUSTAKA}

Chotimah, Siti dan Mundilarno. (2020). Manajemen Kesiswaan Terhadap Hasil Belajar Siswa SMK Swasta Yogyakarta. Journal Media Manajemen Pendidikan Volume 2.

Chotimah, Chusnul. (2017). Peningkatan Keterampilan Diskusi Siswa Kelas X SMAN Pleret, Bantul Melalui Model Pembelajaran Two Stay Two Stray. Jurnal Ilmiah Edukasi \& Sosial, Volume 8, Nomor 1, Maret 2017, hlm 29-40.

Depdiknas. (2007). Buku Saku Kurikulum Tingkat Satuan Pendidikan Sekolah Menengah Pertama. Jakarta: Depdiknas. 
Fathonah, Nur dan Yudhawati, Ulin. (2019). Peningkatan Aktivitas dan Hasil Belajar Siswa Melalui Model Problem Based Learning.UNION: Jurnal Pendidikan Matematika Volume 7. No 3.

Fitriyah. (2012). Efektivitas Two Stay Two Stray terhadap Aktivitas dan Hasil Belajar Siswa. Unnes Journal of Biology Education 1(2).

Hamalik, Oemar. (2009). Proses Belajar Mengajar. Jakarta: PT Bumi Aksara.

Huda, Miftahul. (2015). Cooperative Learning. Yogyakarta: Pustaka Pelajar.

Johnson \& Johnson. 1989. Cooperative Learning. Diakses tanggal 15 Desember 2007. Jam10.30 dari http://www.co-operation.org/pages/cl.html.

Lie, Anita. (2005). Cooperative Learning: Mempraktikkan Cooperative Learning di RuangRuang Kelas. Jakarta: Gramedia Widiasarana Indonesia.

Saiful, Asep Al Fazr. (2016). Penerapan Model Pembelajaran Jigsaw untuk Meningkatkan Hasil Belajar dalam Menemukan Kalimat Utama pada Tiap Paragraf. Jurnal. Sumedang: Universitas Sumedang. Volume 1 No. 1

Sari, F.W. (2010). Penerapan Model Pembelajaran Kooperatif Model Two Stay Two Stray dengan Pendekatan Kontekstual untuk Meningkatkan Motivasi dan Hasil Belajar Biologi Siswa Kelas VII A SMP N 2 Kertosono Jawa Timur. Malang: Online at http://karyailmiah.um.ac.id/index.php/biologi/article/view/9483.

Sudjana, Nana. (2005). Dasar-Dasar Proses Belajar Mengajar. Bandung: Sinar Baru.

Sardiman. 2006. Interaksi dan Motivasi Belajar Mengajar. Jakarta : Bina Aksara.

Winkel, W.S. (1987). Psikologi Pengajaran. Jakarta: PT Gramedia

Yamin, Martinis, (2007). Kiat Membelajarkan Siswa. Jakarta. Gaung Persada Press dan Center for Learning Innovation (CLI). 